that more than one blanket has been copied from the same pattern board and that the twenty-four Emmons blankets are divided by their patterns inte two groups. The narrower lateral designs also have their standard motifs, The pictures in all these forms of Northwest Coast decorations are made . up of "design elements," which have been carefully gathered by Lieutenant Emmons, numbered, named, and illustrated (fig. 559). In the elaborate discussion of these elements and their functions, Professor Boas is convinced that the patterns have drifted out from the literal, have become fixed in their essential features, and attempts to represent specific animals are very limited. The patterns remain the same, no matter what animal is represented. Professor Boas, with Lieutenant Emmons and Doctor Swanton as his guides, goes minutely into the discussion of the blanket types one by one. Each pattern board, blanket, dancing apron, shirt, and legging in the whole Emmons collection is then beautifully illustrated, deciphered by Emmons and Swanton; and then examined in detail by Boas singly and comparatively as to designs, arrangement of pattern elements, variations, and colors. Four plates, two of them colored, finish the priceless monograph.

Otis T. Mason.

Nova Guinea. Résultats de l'expédition néerlandaise à la Nouvelle Guinée en roo3 sous les auspices de ARTHUR WichmanN, chef de l'expédition. Vol. III. Ethnography and Anthropology, by G. A. J. VAN DER SANDE. Surgeon Dutch Royal Navy. Leyden: Brill, 1907. 390 p., 50 pl., 216 figs., map.

This well-printed, beautifully illustrated and adequately indexed volume treats of the natives of New Guinea under the following heads : Food, drink and delicacies; clothing and ornament; habitations and furniture ; hunting and fishing; agriculture ; navigation; trade and communications ; industry ; arms ; customs and government ; art ; religion ; anthropology. Throughout, Dr van der Sande's own investigations and observations are compared and correlated with those of other travelers and ethnologists the bibliography (pp. 364-373) contains nearly 300 titles. The illustrations and the text are also admirably arranged for purposes of exact reference. Material is here afforded for the correction of many misstatements and partial truths of explorers and ethnologists. On page r, e. g., we learn that in the regions of Dutch New Guinea under consideration the so-called " edible earth" is used as a pigment, and not as either food or medicine; and at pp. 353-354, "it is shown once more that the Papuan is by no means everywhere dolichocephalic, as still taught by 
Leane and Deniker." The vegetarian habits of the natives have also sen exaggerated, although in the case of the common people animal food a luxury. Abstentions from the eating of pork may be relics of totemssm, but for the fact that blacksmiths practise such a taboo the author suggests "an imitation of the Mohammedan blacksmiths to whom the people are indebted for the smith's craft." The following statement (p. 13) is interesting in view of certain widespread misinformation of a general character: "The Papuan from Humboldt Bay to the Amberno River does not know any kind of stimulating drink. He best likes the milk from the cocoanut and ordinary river or well water, and fortunately has no liking for our fermented liquor or spirits." This is quite different from the abuse of palm wine among the natives of Geelvink bay.

In several places along the coast of New Guinea the use of tobacco was until recently quite unknown. In most places the Papuans (like the Malays) "appear to find the tobacco too strong to chew unmixed." Often the cigarette, like the siri quid, is passed around, even to children. To draw the line between clothing and ornament among the most primitive people of New Guinea is very difficult. The influence of climate does not appear to any extent, and only on the wedding day does the bride put on her bark petticoat, which is really due to the Malay coast traders and navigators, as the Malay name for New Guinea, Papua Tălandjang ("land of the naked Papuans"), itself suggests. The penis-calabash of the men may be more ornament than shame-clothing. As to the tattooing, the author observes (p. 4I): "A beautiful tattooing of a naked person creates in our mind the same impression as a beautiful dress." Among common motifs in tattooing are, for men, the fish-eye, forestleech, hornbill, frog, mollusk, etc. The wearing of feathers and flowers in the hair is widespread. Wigs made of human hair are in vogue " in coast districts situated at such distances from each other that mutual intercourse is excluded" (p. 63) - such wigs being worn "in commemoration and adoration of blood or close relations." The so-called "combs" of the Papuans are used for scratching, not combing. Ornamental armlets are worn by men even more than by women, and, "righthandedness prevailing," the fixed armlet of the left upper arm serves as a place in which to carry all sorts of small articles. Among the types of dwellings in use among the Papuans are the one with the turtle-shaped roof, the pyramid-shaped, the house with a horizontal ridge-pole, etc. The raison d'etre of Papuan pile-dwellings " may be looked for in the greater cleanliness and the better hygiene obtained in this way, but also in the greater security against man and beast which such a dwelling affords" (p. 129). The picture 
(fig. 102) of the natives "making twine from Pandanus fibers" is interesting as an example of coöperative labor. At Lake Sentáni " fishing and repairing nets, as well as diving for fresh-water molluscs, are left to the women," but in some places at the right season fish is so abundant that men and children have to come to their assistance." At Lake Sentani fishing with hook and line is not practised. Agriculture is chiefly the work of women, men going no further than to clear the ground. It is interesting to note concerning the carrying bags, which seem to be manufactured by the women, that on them is often found (carved $a$ jour) the figure of the dog, which is here so often the companion of the women, to whom it seems more attached than to the men, who treat it less sympathetically. The characteristic and universal craft of New Guinea is a "dug-out," some of which boats are said to reach 6o feet in length. A curious commercial development in these parts is the trade in trunks and the sale by one village to another of the right to cut down trees for boatmaking (p. 194). At Lake Sentáni there are "women's boats" and "men's boats." Important culturally is the trade between the western part of New Guinea and the East Indies (Ceram, Macassar, Tidore, Ternate, etc.). This trade even gave rise to Mohammedan settlements on the coast. The coasting trade (e. g., pottery of Point Moresby) is also significant. Among measures of value and currency employed are shells, dogs' teeth, stone adzes, boars' tusks, Trochus rings, stone hatchets, "antique beads," etc. These beads, which derive their value only from their antiquity, are probably of Chinese origin, as are also certain antique glass rings found at various points in the island. According to the author (p. 232), "already in early youth, the qualities of an all round clever workman are developed in the Papuan," and "in the social life of the Papuans the principle of division of labor has made as yet but little progress." Contrary to general opinion, the weaving industry (p. 237) does exist in certain regions of New Guinea, and the first weaving-frame to be described from the island was met with at Tarfia.

In Dutch New Guinea the method of arrow-release in vogue is the "archaic release" of Morse. In shooting, the belly is the point aimed at, whence the development of defensive girdles of bark. Among the Papuans observed by the author " young children, already at an early age, are given in charge of elder sisters ; afterwards the education takes place in the school of practice, the boys participating in the work of the father, the daughters in the more numerous occupations of the mother. By this, children very early become as clever as their parents" (p. 265). In matter of play, the children are "entirely left to themselves" - the 
author "never saw a father or a mother playing with the children." In Dutch New Guinea circumcision of boys is not practised, although known in certain other parts of the island. On Humboldt bay and at Lake Sentáni "before marriage absolute chastity is the rule" (p. 266). In several parts of New Guinea a "two children system" prevails. Married women also have sometimes (as, e. g., at Humboldt bay), their own property to which the husband has no right. The existence of "manhouses," on the one hand, in some regions, and of communal dwellings, on the other, in certain other regions, "replaces for the greater part family life" (p. 276). This is why "the ties between parents and their children on Netherlands territory are less tender than, e. g., in K. W. Land, from where touching examples are given." Respecting art, we are told (p. 283): "Every Papuan possesses a certain artistic sense, and all are accustomed to apply it. It is for this reason that no member of Papuan society makes art his sole means of existence." Nevertheless, " entire villages may possess a kind of monopoly of producing articles of native, technical art." It is a curious fact (p. 286) that " real picturewriting, - pictography, - recording events, and giving by a series of pictures a connected story of an event, does not appear to occur on N. G." But " the ornament of the Papuan represents a kind of writing, expressing ideas, and giving a legible form to thought," - the natives of Asé, e. g., termed the author's writing äne, "ornament," and seemed "quite familiar with the idea of writing." The chapter on religion (pp. $286-31_{4}$ ) is of special interest, particularly the account of the "temples," in which "the principal spirits reside," and where "the religious life is concentrated and uttered in various forms" (p. 290). According to the author, "What strikes one first on entering the temple is that the noisy behavior said to be characteristic of the inhabitant of Humboldt Bay, is not heard inside, and that, as a rule, the little that is spoken is soft, sometimes almost in a whisper" (p. 292). No special costume or dress, "no kneeling or crouching down as an act of veneration in front of the temple, or before the deities worshiped inside," are in vogue, and "bending of the head as an act of devotion is unknown in Papua Tảlandjang." Inside the "temple" the sacred bamboo plates are kept. The proceedings inside are described at pp. 297-299 as witnessed by the author. These " temples" serve as puberty-houses for young men, and the presence or even near approach of women is tabooed. Open-air singing and dancing are common (p. 308), and, among the people of Mapār, "with their numerous dances which take place inside the house, men, women, and children are placed in separate rows, but dance all at the same time." 
Chapter XIII (pp. $3{ }^{I} 5^{-36}{ }_{3}$ ) is devoted to (physical) anthropology. A larger use of the left hand than is customary with Europeans is noted

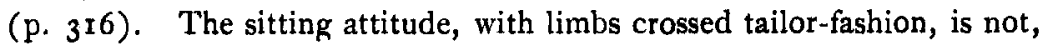
as Deniker thinks, "an ethnic character of the Papuans." The Papuan seemingly "prefers pulling to pushing." The tribes farther in the interior "possess in a much smaller measure the characteristic of being noisy and laughter-loving" (p. 3I 7 ). Meyer's mistaken report that the people of Arfak could not count beyond five is explained by "the fact that the fingers of both hands have the same name as the toes of both feet" (p. 32I). The linguistic material, besides place-names and the appellations of all manner of objects, in this book consists of the numerals of several tribes, a vocabulary from Lake Sentani, and briefer ones from Angádi, Nagramádu, etc. In this chapter a number of interesting physiological details are given. Altogether, the present volume furnishes an excellent apergu of the Papuans of one region of the great island of New Guinea, with the data so arranged as to be readily accessible and usable.

Alexander F. Chamberlain.

\section{SOME NEW PUBLICATIONS}

Ambrosetti, Juan B. Exploraciones arqueológicas en la ciudad prehistórica de "La Paya" (Valle Calchaquí - Provincia de Salta) campañas de 1906 y 1907. Publicaciones de la Sección Antropológica, Facultad de Filosofia y Letras, No. $3,1^{2}$ parte. Buenos Aires: 1907. $8^{\circ}, 278$ p., 121 fig., map.

Aranzadi, Telesforo de. Problemas de etnografía de los Vascos. Extracto de la "Revista Internacional de los Estudios Vascos." Paris : Paul Geunther, 1907. $8^{\circ}$, 50 p., ill.

Arvelo, Martín Matos. Algo sobre etnografía del territorio Amazonas de Venezuela. Ciudad-Bolívar: Imprenta de Benito Jimeno Castro, 1908. $16^{\circ}, 26 \mathrm{p}$.

BANDELIER, AD. F. The Indians and aboriginal ruins near Chachapoyas in northern Peru. [Reprinted from Historical Records and Studies of the United States Catholic Historical Society, v, pt. I, New York, 1907.] $8^{\circ}$, 5 I p., I 3 pl.

Boas, Franz. Second Report on the Eskimo of Baffin Land and Hudson bay. From notes collected by Captain George Comer, Captain James S. Mutch, and Rev. E. J. Peck. Bull. Am. Mus. Nat. Hist., xv, pt. 2, New York, 1907, 80, 371-570 p., ill. 